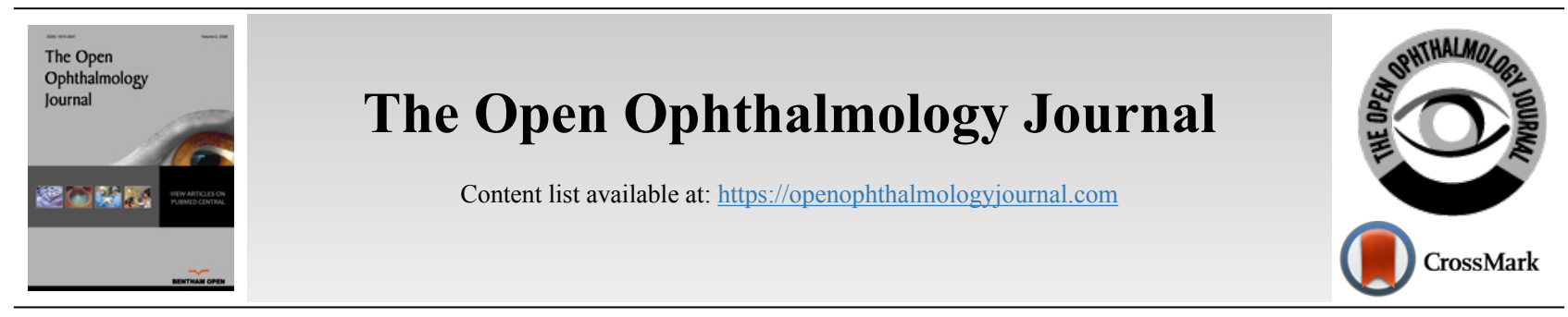

RESEARCH ARTICLE

\title{
Assessment of Coronavirus in the Conjunctival Tears in Pediatric Patients with Asymptomatic COVID-19 Infection in Sohag Government, Egypt
}

\author{
Hany Mahmoud ${ }^{1, *}$, Ahmed Radwan², Amr El Rashidy ${ }^{3}$, Hesham M. Hefny ${ }^{4}$, Amal H. Ali $^{5}$ and Amr Mounir ${ }^{1}$ \\ ${ }^{I}$ Department of Ophthalmology, Sohag University, Sohag, Egypt \\ ${ }^{2}$ Department of Rheumatology, Sohag University, Sohag, Egypt \\ ${ }^{3}$ Sohag Tropical Hospital, Tropical Medicine, Sohag, Egypt \\ ${ }^{4}$ Department of Clinical Pathology, Sohag University, Sohag, Egypt \\ ${ }^{5}$ Department of Microbiology and Immunology, Aswan University, Tingar, Egypt
}

\begin{abstract}
:
Objective:

The present study aims to evaluate coronavirus shedding in the tears of asymptomatic pediatric COVID-19 positive patients.

Methods:

A prospective interventional study that included a total of 145 pediatric asymptomatic COVID-19 patients hospitalized from $17^{\text {th }}$ May 2020 to $16^{\text {th }}$ July 2020 in Sohag Tropical Hospital. On admission, all of them were COVID-19 positive detected through nasopharyngeal swab. They were in intimate contact with positive symptomatic COVID-19 patients before testing and admission. Reverse Transcriptase Polymerase chain reaction (RT-PCR) was done for tears samples at an interval of 5 days after admission and twice before discharge.

Results:

Of the 145 asymptomatic pediatric COVID-19 positive patients, no one showed ocular or systemic manifestations. They were silent carriers. Ten were positive for tears sample on admission. They became negative for nasopharyngeal and tear samples before discharge.

\section{Conclusion:}

Pediatric positive COVID-19 patients can shed coronavirus through their tears. Even among asymptomatic patients, transmission through tears is possible.
\end{abstract}

Keywords: Asymptomatic, Conjunctiva, Coronavirus, Pediatric, RT-PCR, Tears.

\begin{tabular}{l|l|l|l}
\hline Article History & Received: December 18, 2020 & Revised: January 18, 2021 & Accepted: February 28, 2021
\end{tabular}

\section{INTRODUCTION}

In December 2019, the coronavirus emerged in Wuhan (China) and spread all over the world, causing a major health problem. Therefore, World Health Organization (WHO) announced that it is a pandemic $[1,2]$. The pathogen is called severe acute respiratory syndrome coronavirus 2 (SARS-Co V-2). It causes respiratory, gastrointestinal, and ocular [3] symptoms as well as fever. However, some patients have no symptoms, so they represent a major threat because they are silent carriers to the pathogen $[4,5]$.

There are many routes for virus transmission, such as drop-

\footnotetext{
* Address correspondence to this author at Department of Ophthalmology, Sohag University, Sohag, Egypt; Tel: 01024368111;

E-mail: drhanymahmoud@gmail.com
}

droplets and breath [6,7]. Coronavirus shedding in ocular secretions among adults suggests its transmission through ocular secretion and tears [8 - 13]. Many studies showed that pediatric patients could show mild symptoms or no symptoms at all, but they are a potential source for infection $[14,15]$.

In pediatric groups with COVID-19 without symptoms, shedding the virus in tears and ocular secretions has not been evaluated yet. The present paper aims to evaluate its shedding in ocular tears and secretion and clarify the potential infectivity of asymptomatic pediatric patients.

\section{METHODS}

It is a prospective interventional study that included a total of 145 pediatric asymptomatic COVID-19 patients. Pediatric 
(up to 18 years) COVID-19 patients were included in this prospective observational case series study.

All patients included in this study were evaluated as follows: History including contact with confirmed positive COVID-19 patients and clinical symptoms. They were examined regarding systemic and ocular signs. The ocular examination was done using side examination with diffuse illumination or portable slit-lamp. Laboratory tests were done using RT-PCR for nasopharyngeal swabs and conjunctival swabs once on admission and repeated during admission and once before discharge to confirm negativity. We used StepOne (RT-PCR) system (Applied Biosystem ${ }^{\circledR} 7500$ (RT-PCR) System, CA, USA) with detection of 0.58 copies $/ \mu \mathrm{L}$ of COVID-19 viral RNA with a confidence $\geq 95 \%$ (Fig. 1). Laboratory tests were conducted according to the guidelines of the Egyptian Ministry of Health.

We collected conjunctival swabs from the lower conjunctival fornix without using any topical anesthesia to avoid contamination. All precautions regarding personal protective equipment (PPE) were taken according to the guidelines.

\subsection{Ethical Considerations}

This study was approved by the Al-Shahid Hospital Ethical Committee and adhered to the tenets of the Declaration of Helsinki. Written Informed consent was obtained from the patients and their families. IBR registration number: S26-144.

\subsection{Method of Conjunctival Swab}

First, conjunctival swabs were obtained after a time interval of 5 days after admission due to respiratory symptoms to ensure the presence of high viral load levels detected by RTPCR $[16,17]$ with which tears samples are tested again before discharge. Personal Protective Equipment (PPE) was used for tear film swabs as personal protective equipment.

Conjunctival swabs were obtained from samples of the inferior conjunctival sac 18 and collected through virus specimen transport for Molecular and Culture Techniques (Sigma Virocult ${ }^{\circledR}$ ). It was performed after eversion of the lower eyelids by sterile cotton tips to explore the lower fornices of the lower eyelid. Topical anesthesia was not used and the tips of the sterile sticks were placed into liquid Virocult ${ }^{\circledR}$ medium solution. Sterile gloves were changed to avoid contamination risk either for the collected samples or examined patients. Samples were put on ice tanks and rapidly transmitted to the PCR laboratory

Technique of qualitative Real time PCR for the detection

\section{of SARS-CoV-2 viral RNA}

\section{1- RNA Extraction}

SARS-CoV-2 viral RNA extraction was performed using specific kits; Qiagen columns (QIAamp DSP Virus spin kit, cat. No. 61704, QIagen Inc.) and using a fully automated QIAcube instrument following the manufacturer's instructions.

2- Real time quantitative PCR:

SARS-CoV-2 viral RNA assay was performed using specific TaqMan ${ }^{\circledR}$ probe-based technology (The Genesig ${ }^{\circledR}$ (RT-PCR) Coronavirus (COVID-19) kit cat. No. Z-PathCOVID-19-CE, Primerdesign Ltd)). The analysis was performed using StepOne (RT-PCR) system (Applied Biosystem ${ }^{\circledR} 7500$ (RT-PCR) System, CA, USA).

The master mix was added to the number of wells required for testing and it was prepared by adding $10 \mu$ oasig qPCR OneStep Master Mix and $2 \mu$ COVID-19 CE IVD Primer/Probe. The reaction was performed in a $20 \mu \mathrm{L}$ reaction volume containing $12 \mu \mathrm{L}$ of Master Mix and $8 \mu \mathrm{l}$ of the following (the sample extract, negative extraction control (NEC) or positive control template (PCT)). The real-time cycler conditions were performed according to the following conditions:

\subsection{Statistical Analysis}

Statistical analysis was done using IBM-SPSS version 25 (IBM corporation, Chicago, USA, August 2017). Data were expressed as Mean $\pm \mathrm{SD}$ for quantitative data as well as numbers and percentages for qualitative data. Comparison between the means of the quantitative data was made using Mann-Whitney test and comparison between the percentages of the qualitative data was done using Fisher exact test. P-value of $<0.05$ was considered statistically significant.

\section{RESULTS}

The results are summarized in Tables $\mathbf{1}$ - 4 . 145 asymptomatic pediatric COVID-19 patients were included in the group. They were in intimate contact with other positive patients. Moreover, they were tested by RE-PCR and were positive for COVID-19. They were admitted and isolated to avoid the spread of infection and to be treated.

The mean age was 160 months with a range 6: 212 months (0.6-17.6 years old):75 (51.7\%) were males and 70 (48.3\%) were females. On admission, no one had any registered symptoms or signs, either systemic or ocular. They were all asymptomatic till the end of the study. Patients who showed no symptoms or signs were excluded from the study (Table $\mathbf{1}$ ).

Table 1. Parameters of real-time cycler of PCR.

\begin{tabular}{|c|c|c|}
\hline Steps & Time & Temperature \\
\hline Reverse transcription & $10 \min$ & $55^{\circ} \mathrm{C}$ \\
\hline Initial denaturation (Taq activation) & 2 min & 1 \\
\hline Denaturation & 10 sec. & $95^{\circ} \mathrm{C}$ \\
\hline Primer annealing and extension & 60 sec. & $95^{\circ} \mathrm{C}$ \\
\hline
\end{tabular}


Table 2. Showing characters of included patients.

\begin{tabular}{|c|c|}
\hline Item & Value \\
\hline Age (in months) & $122.5 \pm 73.1$ \\
\hline Mean \pm SD & $145(6-212)$ \\
\hline Median (Range) & $76(52.4 \%$ \\
\hline Sex & $69(47.6 \%)$ \\
\hline Male; $n$ (\%) & 0 \\
\hline Female; $n$ (\%) & $145(100 \%)$ \\
\hline Symptoms & $145(100 \%)$ \\
\hline With symptoms (either systemic or ocular) & $10(6.9 \%)$ \\
\hline Without symptoms (either systemic or ocular) & \\
\hline $1^{\text {st }}$ swab on admission & \\
\hline $1^{\text {st }}$ nasopharyngeal swab & \\
\hline $1^{\text {st }}$ conjunctival swab & \\
\hline
\end{tabular}

Table 3. Showing results of 2 nd and 3rd swabs.

\begin{tabular}{|c|c|c|c|}
\hline No of swab & Nasopharyngeal & Conjunctival & Percentage of conjunctival positive among nasopharyngeal positive cases \\
\hline First & $145(100 \%)$ & $10(6.9 \%)$ & $6.90 \%$ \\
\hline Second & $33(22.8 \%)$ & $2(1.38 \%)$ & $6.06 \%$ \\
\hline Third & 0 & 0 & - \\
\hline
\end{tabular}

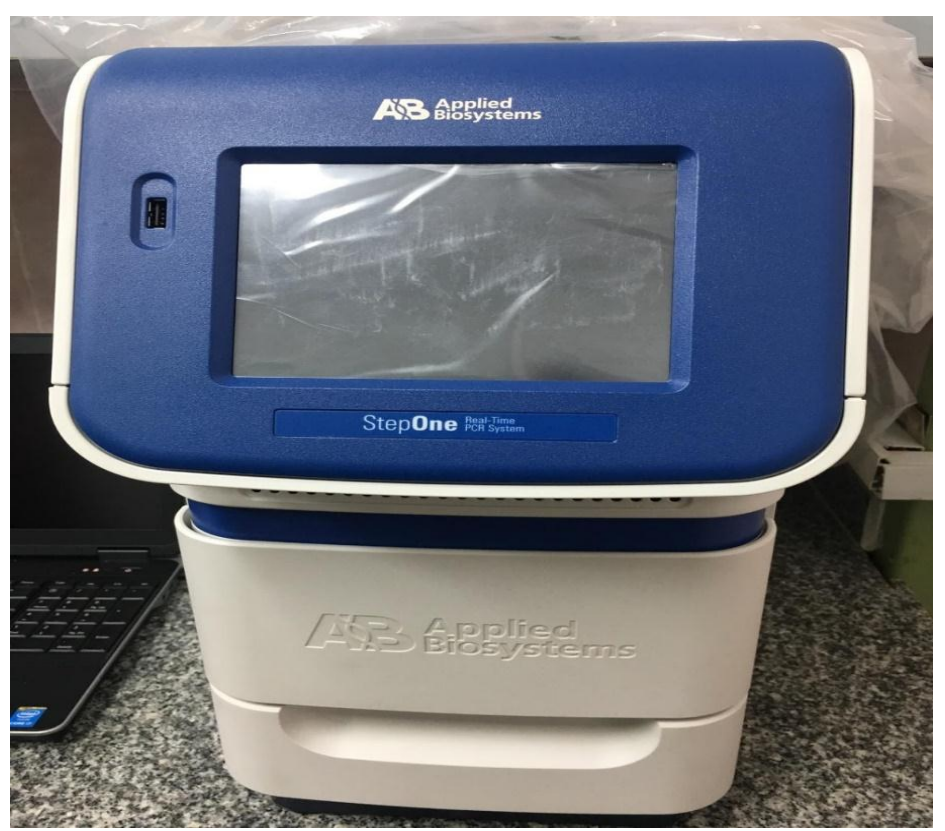

Fig. (1). The used PCR system.

On admission, all were positive for nasopharyngeal swabs, and only $10(6.9 \%)$ were positive for conjunctival swabs Table 2.

According to guidelines, two nasopharyngeal swabs were done before discharge. Also, two conjunctival swabs were done before discharge. The $2^{\text {nd }}$ nasopharyngeal swab was positive in $33(22.76 \%)$ patients and negative in $112(77.24 \%)$ patients.
The $3^{\text {rd }}$ nasopharyngeal swab was negative in all patients before discharge. Regarding conjunctival swabs, the $2^{\text {nd }}$ conjunctival swab was positive in $2(1.38 \%)$ patients, and the third was negative in all patients (Table 3 and Fig. 2).

Regarding the clinical and demographic relation with a positive conjunctival swab, age and sex showed no significant relation with positive conjunctival swab (Table $\mathbf{3}$ and Figs. $\mathbf{3}$ and 4). 
Table 4. Showing clinical and demographic relation with positive conjunctival swab.

\begin{tabular}{|c|c|c|c|}
\hline Item & & $\begin{array}{c}\text { First } \\
\text { conjunctival swab }\end{array}$ & Second conjunctival swab \\
\hline Sex & Male & $6(7.9 \%)$ & $2(2.6 \%)$ \\
\hline & Female & $4(5.8 \%)$ & $0.498^{*}$ \\
\hline Age & P value & $0.748^{*}$ & $108.0 \pm 128.7$ \\
\hline & Mean among positive cases & $139.8 \pm 70.3$ & $121.9 \pm 73.1$ \\
\hline Breast feeding & Mean among negative cases & $0.601 \wedge$ & $0.886^{\wedge}$ \\
\hline & P value & $2(5.7 \%)$ & $1(2.9 \%)$ \\
\hline & Yes & $8(7.3 \%)$ & $1(0.9 \%)$ \\
\hline
\end{tabular}

* Fisher exact test was used, $\wedge$ Mann Whitney test was used

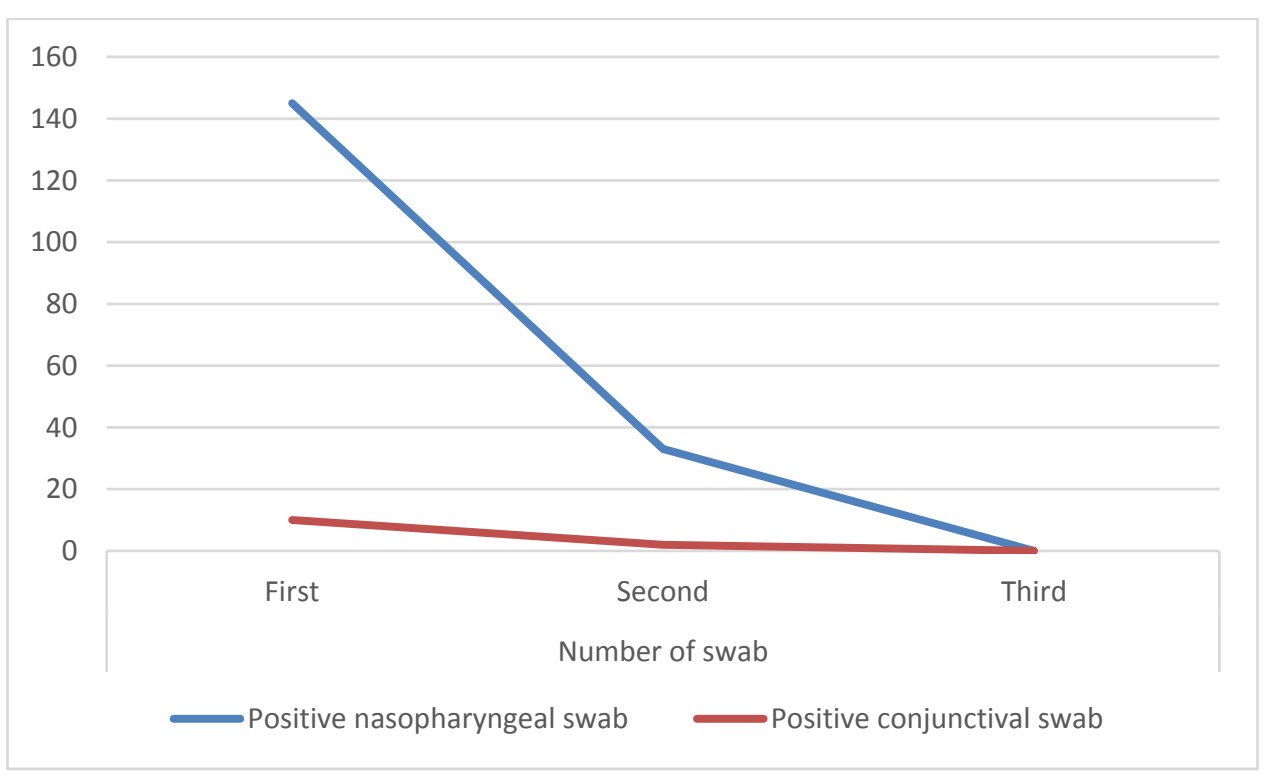

Fig. (2). Comparison between positive nasopharyngeal swab and conjunctival swab.

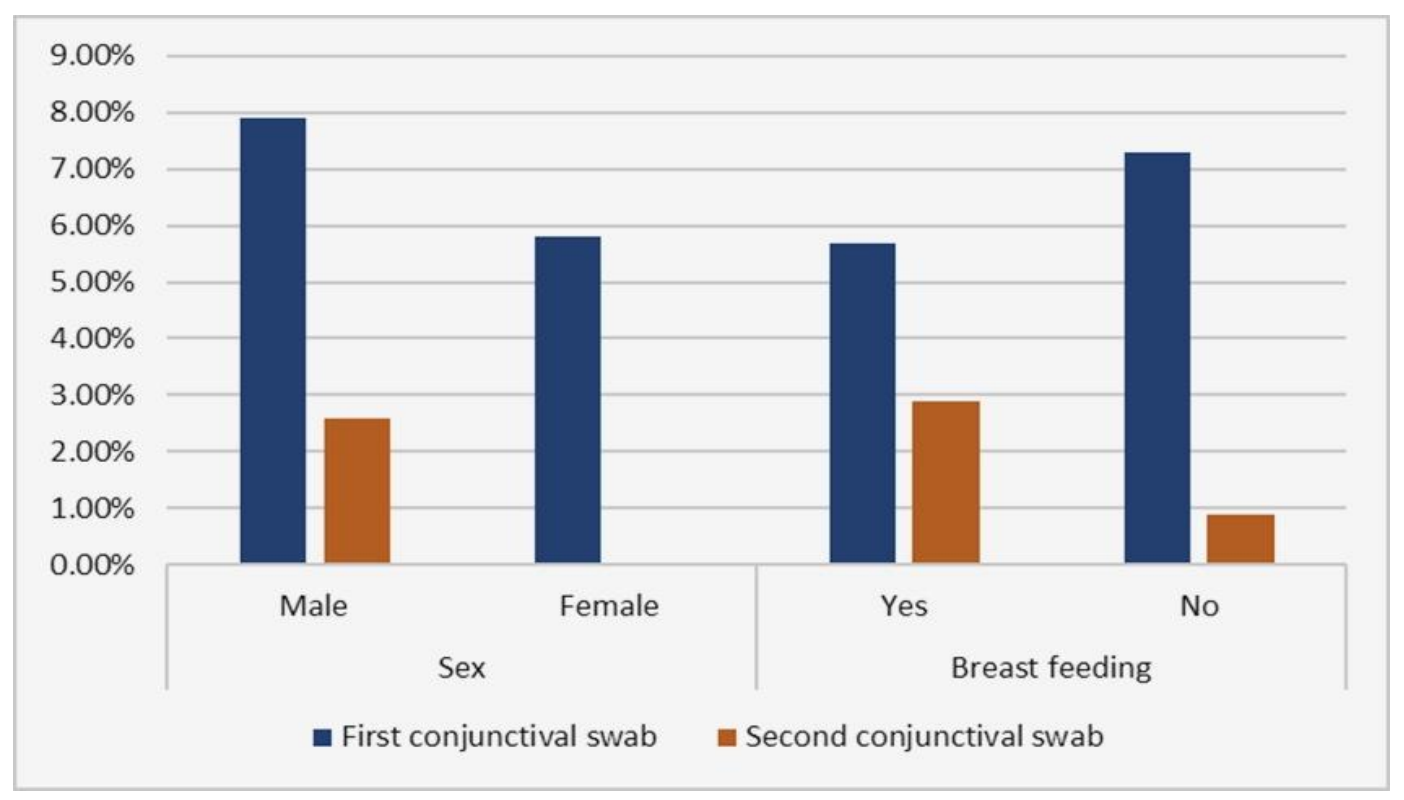

Fig. (3). Comparison between positive conjunctival swab and sex and breast feeding. 


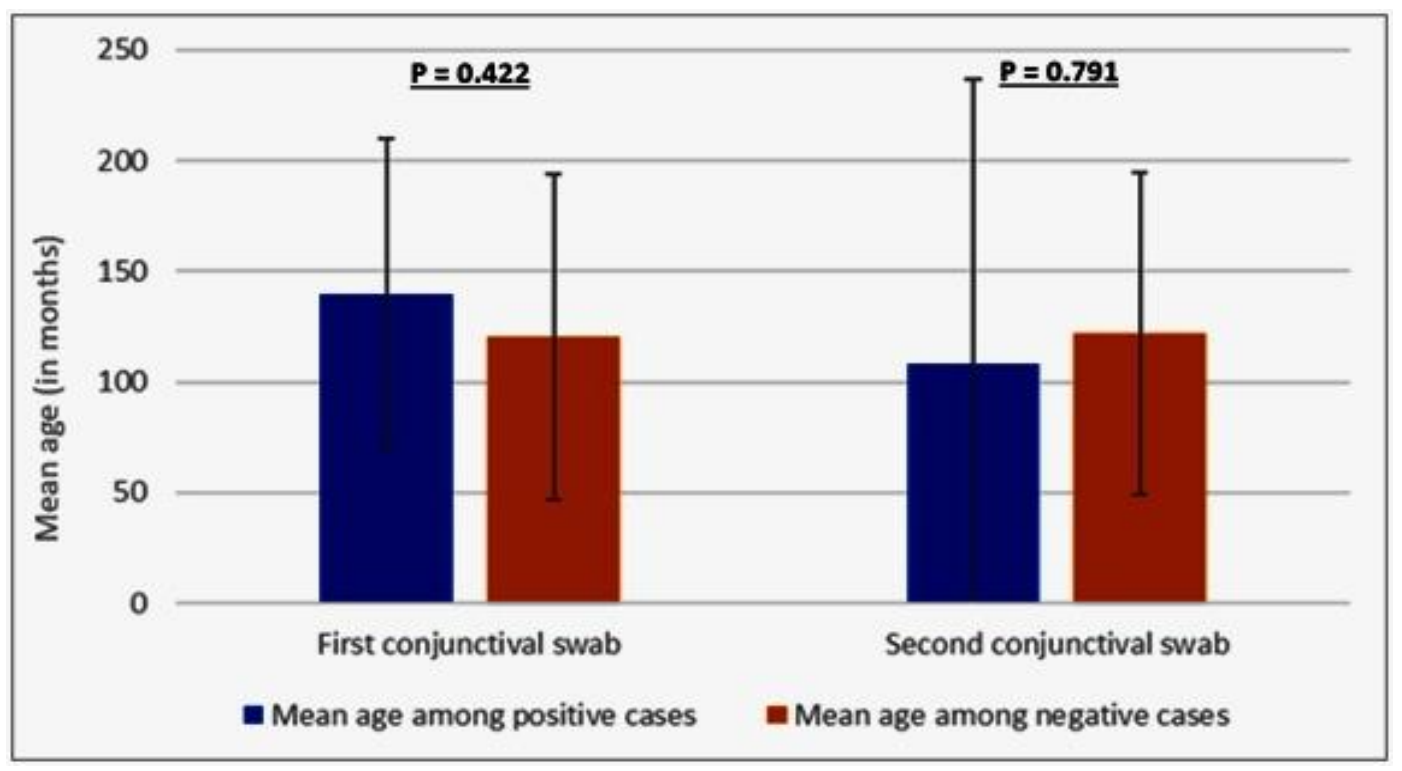

Fig. (4). Comparison between positive conjunctival swab and age.

\section{DISCUSSION}

SARS-CoV- 2 is more liable to infect the elderly population. However, the virus is thought to have a milder effect on the pediatric group of population $[19,20]$.

The pediatric age group is potentially dangerous as they could be infected by coronavirus without any symptoms. In other words, they are silent carriers and could spread the infection through droplets and other routes. Many studies suggest that tears, as a source of infection, are supported by the presence of the virus in conjunctival tears and secretions [21].

In the present paper, we evaluated shedding coronavirus in the tears of asymptomatic pediatric COVID-19 positive patients. The present paper aimed to assert or exclude the presence of the virus in the tears and conjunctival secretions of pediatric population who are considered a silent carrier.

Different studies attempted to evaluate the presence of coronavirus in ocular secretions in adults. For example, Kaya $\mathrm{H}$ et al. [22] found that 5 of 32 patients without conjunctivitis had viral RNA in their tear-conjunctival samples. Karimi $\mathrm{S}$ et al. [23] reported that $7 \%$ of the coronavirus- 2 patients had viral RNA in their conjunctival secretions. Wu $\mathrm{P}$ et al. [24] evaluated ocular manifestations and viral prevalence in the conjunctiva of patients with COVID-19. The study showed a low prevalence of SARS-CoV-2 in tears.

The aforementioned results are consistent with Valente $\mathrm{P}$ et al. [25] who evaluated the virus shedding in the tears of pediatric population with symptoms either systemic or ocular. The study indicated that even those with no symptoms could shed the virus in conjunctival secretions.

Minority of pediatric population showed mild to severe COVID-19 manifestations. However, in this study, only those with no manifestations were included with the exclusion of symptomatic cases.

This study showed that even with no systemic or ocular symptoms, the coronavirus can be found in conjunctival tears and secretions. Although it appears in a low percentage of people, it may be a source of infection.

In this study, the presence of the virus in tears has less duration than its presence in the nasopharyngeal swabs. This appeared in the low percentage of negative 2 nd conjunctival swab with a higher percentage of positive nasopharyngeal swabs, which may be due to low virus load in the conjunctiva. It disappeared earlier than other body tissues or might be attributed to false-negative results and decreased accuracy of methods used for coronavirus evaluation in the tears and conjunctival secretions [26]

The ocular tissues are good media for virus replication. It could be shredded by ocular secretions. This fact could explain the infection rate among ophthalmologists. It may be attributed to droplet infection or ocular secretions. Hence, it is recommended that ophthalmologists should take all safety measures during their practice [27]

\section{CONCLUSION}

In conclusion, pediatric positive COVID-19 patients can shed coronavirus in their tears. Even among asymptomatic patients, transmission through tears is possible.

\section{LIMITATIONS}

Small sample size with false-negative results of RT-PCR.

\section{RECOMMENDATIONS}

The present paper recommends evaluating the accuracy of coronavirus detection tests in tears. Furthermore, further studies on asymptomatic patients have to be conducted.

\section{ETHICS APPROVAL AND CONSENT TO PARTI- CIPATE}

This study was approved by the Al-Shahid Hospital Ethical Committee, Egypt under IBR registration number: S26-144. 


\section{HUMAN AND ANIMAL RIGHTS}

No Animals were used in this research. All human research procedures followed were in accordance with the ethical standards of the committee responsible for human experimentation (institutional and national), and with the Helsinki Declaration of 1975, as revised in 2013.

\section{CONSENT FOR PUBLICATION}

Written Informed consent was obtained from the patients and their families.

\section{AVAILABILITY OF DATA AND MATERIALS}

The data that support the findings of this study are available from the corresponding author, [H.M] upon reasonable request.

\section{FUNDING}

None.

\section{CONFLICT OF INTEREST}

The authors declare no conflict of interest, financial or otherwise.

\section{ACKNOWLEDGEMENETS}

Declared none.

\section{REFERENCES}

[1] Rothan HA, Byrareddy SN. The epidemiology and pathogenesis of coronavirus disease (COVID-19) outbreak. J Autoimmun 2020; 109102433

[http://dx.doi.org/10.1016/j.jaut.2020.102433] [PMID: 32113704]

[2] Mahase E. Covid-19: WHO declares pandemic because of "alarming levels" of spread, severity, and inaction. BMJ 2020; 368: m1036. [http://dx.doi.org/10.1136/bmj.m1036] [PMID: 32165426]

[3] Adhikari SP, Meng S, Wu YJ, et al. Epidemiology, causes, clinical manifestation and diagnosis, prevention and control of coronavirus disease (COVID-19) during the early outbreak period: A scoping review. Infect Dis Poverty 2020; 9(1): 29.

[http://dx.doi.org/10.1186/s40249-020-00646-x] [PMID: 32183901]

[4] Rothe C, Schunk M, Sothmann P, et al. Transmission of 2019-nCoV infection from an asymptomatic contact in germany. N Engl J Med 2020; 382(10): 970-1.

[http://dx.doi.org/10.1056/NEJMc2001468] [PMID: 32003551]

[5] Bai Y, Yao L, Wei $\mathrm{T}$, et al. Presumed asymptomatic carrier transmission of COVID-19. JAMA 2020; 323(14): 1406-7. [http://dx.doi.org/10.1001/jama.2020.2565] [PMID: 32083643]

[6] Choi SH, Kim HW, Kang JM, Kim DH, Cho EY. Epidemiology and clinical features of coronavirus disease 2019 in children. Clin Exp Pediatr 2020; 63(4): 125-32.

[http://dx.doi.org/10.3345/cep.2020.00535] [PMID: 32252139]

[7] Riou J, Althaus CL. Pattern of early human-to-human transmission of Wuhan 2019 novel coronavirus (2019-nCoV), December 2019 to January 2020. Euro Surveill 2020; 25(4)2000058

[http://dx.doi.org/10.2807/1560-7917.ES.2020.25.4.2000058] [PMID: 32019669]

[8] Colavita F, Lapa D, Carletti F, et al. SARS-CoV-2 Isolation from ocular secretions of a patient with COVID-19 in Italy with prolonged viral RNA detection. Ann Intern Med 2020; 173(3): 242-3. [http://dx.doi.org/10.7326/M20-1176] [PMID: 32302380]

[9] Lu CW, Liu XF, Jia ZF. 2019-nCoV transmission through the ocular surface must not be ignored. Lancet 2020; 395(10224)e39
[http://dx.doi.org/10.1016/S0140-6736(20)30313-5]

[PMID: 32035510]

[10] Xia J, Tong J, Liu M, Shen Y, Guo D. Evaluation of coronavirus in tears and conjunctival secretions of patients with SARS-CoV-2 infection. J Med Virol 2020; 92(6): 589-94.

[http://dx.doi.org/10.1002/jmv.25725] [PMID: 32100876]

[11] Seah IYJ, Anderson DE, Kang AEZ, et al. Agrawal R. Assessing viral shedding and infectivity of tears in coronavirus disease 2019 (COVID-19) patients. Ophthalmology 2020; 6461-6420(20): 30311-0.

[12] Mahmoud H, Ammar H, El Rashidy A, Ali AH, Hefny HM, Mounir A. Assessment of coronavirus in the conjunctival tears and secretions in patients with SARS-CoV-2 infection in sohag province, egypt. Clin Ophthalmol 2020; 14: 2701-8.

[http://dx.doi.org/10.2147/OPTH.S270006] [PMID: 32982162]

[13] Loon SC, Teoh SC, Oon LL, et al. The severe acute respiratory syndrome coronavirus in tears. Br J Ophthalmol 2004; 88(7): 861-3. [http://dx.doi.org/10.1136/bjo.2003.035931] [PMID: 15205225]

[14] Lu X, Zhang L, Du H, Zhang J, Li YY. SARSCoV-2 infection in children 2020. N Engl J Med 2000; 10.

[15] Patel NA. Pediatric COVID-19: Systematic review of the literature. Am J Otolaryngol 2020; 41(5)102573 [http://dx.doi.org/10.1016/j.amjoto.2020.102573] [PMID: 32531620]

[16] Pan Y, Zhang D, Yang P, Poon LLM, Wang Q. Viral load of SARSCoV-2 in clinical samples. Lancet Infect Dis 2020; 20(4): 411-2. [http://dx.doi.org/10.1016/S1473-3099(20)30113-4] [PMID: 32105638]

[17] Huang Y, Chen S, Yang Z, et al. SARS-Cov-2 viral load in clinical samples from critically ill patients. Am J Respir Crit Care Med 2020; 201(11): 1435-8.

[http://dx.doi.org/10.1164/rccm.202003-0572LE] [PMID: 32293905]

[18] Lamagna B, Pasolini MP, Nizza S, et al. Conjunctival cytological examination, bacteriological culture and antimicrobial resistance profiles of healthy Mediterranean buffaloes (Bubalus bubalis) from Southern Italy. Asian Pac J Trop Biomed 2015; 5(11): 889-95.

[http://dx.doi.org/10.1016/j.apjtb.2015.06.017]

[19] Sun D, Li H, Lu XX, et al. Clinical features of severe pediatric patients with coronavirus disease 2019 in Wuhan: A single center's observational study. World J Pediatr 2020; 16(3): 251-9.

[http://dx.doi.org/10.1007/s12519-020-00354-4] [PMID: 32193831]

[20] Chen Y, Peng H, Wang L, et al. Infants born to mothers with a new coronavirus (COVID-19). Front Pediatr 2020; 8: 104.

[http://dx.doi.org/10.3389/fped.2020.00104] [PMID: 32266184]

[21] Cao Q, Chen YC, Chen CL, Chiu CH. SARS-CoV-2 infection in children: Transmission dynamics and clinical characteristics. J Formos Med Assoc 2020; 119(3): 670-3.

[http://dx.doi.org/10.1016/j.jfma.2020.02.009] [PMID: 32139299]

[22] Kaya H, Çalışkan A, Okul M, Sarı T, Akbudak İH. Detection of SARS-CoV-2 in the tears and conjunctival secretions of Coronavirus disease 2019 patients. J Infect Dev Ctries 2020; 14(9): 977-81.

[http://dx.doi.org/10.3855/jidc.13224] [PMID: 33031084]

[23] Karimi S, Arabi A, Shahraki T, Safi S. Detection of severe acute respiratory syndrome Coronavirus- 2 in the tears of patients with Coronavirus disease 2019. Eye (Lond) 2020; 34(7): 1220-3.

[http://dx.doi.org/10.1038/s41433-020-0965-2] [PMID: 32424329]

[24] Wu P, Duan F, Luo C, et al. Characteristics of ocular findings of patients with coronavirus disease 2019 (COVID-19) in hubei province, china. JAMA Ophthalmol 2020; 138(5): 575-8.

[http://dx.doi.org/10.1001/jamaophthalmol.2020.1291] [PMID: 32232433]

[25] Valente P, Iarossi G, Federici M, et al. 2020.https://doi.org/10.1016/

[26] Lin C, Ye R, Xia YL. A meta-analysis to evaluate the effectiveness of real-time PCR for diagnosing novel coronavirus infections. Genet Mol Res 2015; 14(4): 15634-41.

[http://dx.doi.org/10.4238/2015.December.1.15] [PMID: 26634531]

[27] Mahmoud H. Safety measures in ophthalmology practice in COVID-19 era. NILES Geriatric and Gerontology, 3(COVID-19) 2020; 1-6. 